\title{
FISH-DIVERSITY IN THE KURA RIVER OF BANGLADESH: PATTERNS AND THREATS
}

\author{
SANZIB KUMAR BARMAN ${ }^{1 \#}$, MRITYUNJOY KUNDA ${ }^{1}$, SABUJ KANTI MAZUMDER $^{2 *}$, \\ MD. NAHIDUZZAMAN ${ }^{3}$, PARTHO PROTIM BARMAN ${ }^{4,5}$ and SIMON KUMAR DAS 6 \\ ${ }^{1}$ Aquatic Resource Management, Faculty of Fisheries, \\ Sylhet Agricultural University, Sylhet 3100, Bangladesh \\ ${ }^{2}$ Genetics and Fish Breeding, Bangabandhu Sheikh Mujibur Rahman Agricultural University, \\ Gazipur 1706, Bangladesh \\ ${ }^{3}$ WorldFish, Bangladesh and South Asia, Dhaka 1213, Bangladesh \\ ${ }^{4}$ Coastal and Marine Fisheries, Sylhet Agricultural University, Sylhet 3100, Bangladesh \\ ${ }^{5}$ College of Fisheries, Ocean University of China, Qingdao 266003, China \\ ${ }^{6}$ Department of Earth Sciences and Environmental, Faculty of Science and Technology, \\ Universiti Kebangsaan Malaysia, 43600 UKM Bangi Selangor, D.E., Malaysia \\ \#Current address: Department of Fishery Resources Conservation \& Management, \\ Faculty of Fisheries \& Ocean Sciences, Khulna Agricultural University, Khulna-9100 \\ *E-mail: sabujgfb@bsmrau.edu.bd
}

Accepted 29 June 2021, Published online 31 December 2021

\begin{abstract}
The study was aimed to investigate the current status and threats of fisheries resources in the Kura River, Bangladesh. Monthly fish catch surveys were carried out from December 2015 to November 2016 in four catchment areas at Hasinarghat, Kandir-dor, Pulertol, and Barartok. In addition, questionnaire interviews and focus group discussions (FGD) were done to clarify perceptions about the Kura River fishery status. A total of 59 fish species from 22 families were documented and of which $27 \%$ were threatened. The values of diversity (H), richness (D), and evenness (J') were calculated at 3.599 , 4.345 , and 0.921 respectively. The highest catch volume was recorded $19800 \pm 7722.71 \mathrm{~kg}$ in November 2016 at the Kandirdor and the lowest $225 \pm 110.65 \mathrm{~kg}$ in March 2016 at the Barartok $(p<0.05)$. The upstream blockage (man-made dam) in the Kura River was identified as the main cause of fish habitat change, decrease fish biodiversity, and production of this River. Therefore, the findings of this study exposed that the conservation of fish has become urgent. In this regard, the baseline scenario of the Kura River biodiversity and threats will help to make awareness to take necessary conservation strategy as well as the need for further in-depth study.
\end{abstract}

Key words: Catch volume, fish diversity, fishing gears, habitat degradation, threats

\section{INTRODUCTION}

Bangladesh is blessed with voluminous rivers and canals making it a riverine country. The Kura River is one of the most important rivers in the northeast part of Bangladesh in terms of fish production and income generation of more than thousands of surrounding fishermen (Banglapedia, 2015). The Kura River is an interconnecting waterway between two important water bodies named Erali Beel upstream and Damri haor the downstream. The Erali Beel is also connected with the river Surma and Damri haor

* To whom correspondence should be addressed. is connected with the river Kushiyara formed two major rivers of Sylhet district in Bangladesh. As an interconnecting water body, the Kura River is rich in fisheries biodiversity. During the winter period (December to March), water flow reduces (average depth becomes 5-6 m) and it acts as a reserve for diversified aquatic species, useful for the next year's breeding. Also, there are many important fishing grounds which locally called Dor, as Fokir marar dor, Senapotir dor, Kunimurar dor, Udorulir dor, Gonar dor, Lalmatir dor, Koikhanir dor, and Laiatokir dor, Pulertol, Botertol, Khaler mukh, Barartok, Solimsah ghat, and Hasinar ghat. Approximately more than 3000 households are living in this area whose 
livelihoods, culture, and daily activities are mainly relying on this aquatic environment (Banglapedia, 2015).

In recent decades, man-made threats such as upstream dam construction, overfishing, use of illegal fishing gears, destruction of fish sanctuaries, and siltation have caused gradual degradation of ordinary habitats as well as decreasing aquatic diversity, a vital problem in Bangladesh (Islam et al., 2015; Pandit et al., 2015a). Studies have indicated the need for detailed biodiversity studies to assess the present status and sustainable management of such water bodies (Chaki et al., 2014; Mohsin et al., 2014; Pandit et al., 2015a; Mazumder et al., 2018). In addition, several studies have been conducted on fish faunal biodiversity in different water bodies of Bangladesh (Galib et al., 2013; Imteazzaman \& Galib, 2013), while no study has been reported on fisheries biodiversity of the Kura River in Sylhet, Bangladesh. Therefore, this study is the first attempt to comprehend the current status, current production, and threats of fisheries diversity in the Kura River.

\section{MATERIALS AND METHODS}

\section{Study area}

The study was conducted in the Kura River at Golapganj upazila (located in between $24^{\circ} 41^{\prime}$ and $24^{\circ} 55^{\prime}$ north latitudes and in between $91^{\circ} 55^{\prime}$ and $92^{\circ} 06^{\prime}$ east longitudes) in Sylhet district, Bangladesh. The total length of the Kura River is about $15 \mathrm{~km}$ with surrounding localities. Field surveys were undertaken at four adjacent villages of Kura River, named Masura, Uttar Gaon, Dakhin Gaon, and Sitessor under Bhadeshwar union of Golapganj upazila. Two criteria for the selection of the study area were suitable geographical coverage for a wide variety of biodiversity and the number of fishermen depending on fishing activities for their livelihood in this area (Figure 1).

\section{Data collection}

Fish sampling was done from all sampling points on monthly basis to study the biodiversity and status of Kura River fisheries. Also, data were collected from interviews and focus group discussions (discussions with a small group of people, generally $12-15$ in numbers have a common interest) with stakeholders to understand the previous scenario of the Kura River fishery. For interview and FGD, semi-structured and structured questionnaires were developed, pretested, and adopted to addressed key issues included present status and causes of fisheries diversity loss with their possible mitigation measures. A total of 284 stakeholders including fishermen, aratdar (acts as a middleman between fisherman and customers), fish traders, housewives, local leaders, Upazila Fisheries Officers (UFO), and District Fisheries Officer participated in this survey. A total of 80 fishermen, 20 fish traders, and 20 aratdars were randomly selected for the questionnaire interview. In each of the four villages, two FGDs were conducted in which FGD1 had 12 and FGD2 had 15 participants (Table 1).

Table 1. Categorization of key stakeholder groups and their roles in the study (DFO $=$ district fisheries officer, UFO $=$ upazilla fisheries officer, FGD = focus group discussion)

\begin{tabular}{lcll}
\hline Stakeholder & Number & Stakeholder role & $\begin{array}{c}\text { Involvement in } \\
\text { the Study }\end{array}$ \\
\hline Fishers & 200 & Depend on Kura River for livelihood & Interview and FGD \\
DFO & 1 & $\begin{array}{l}\text { Implement fish acts and monitoring of the overall fishing activities; } \\
\text { encourages the fishermen to conserve the habitat considering its } \\
\text { great importance }\end{array}$ & Interview \\
UFO & 1 & $\begin{array}{l}\text { Implement fish acts; involvement in the leasing process, and } \\
\text { motivating people for fish conservation and habitat restoration }\end{array}$ & Interview \\
to increase fish production & $\begin{array}{l}\text { Proclamation on conservation, conflict resolution, and policy } \\
\text { involvement at the local level }\end{array}$ & Interview and FGD \\
Hocal Leaders & 10 & Assist fishers by net making & FGD \\
Fish Traders & 20 & Invest in the fishing business, promote fish transportation & Interview \\
Aratders & 20 & $\begin{array}{l}\text { Collects fish from fishers and sell it to other parties; } \\
\text { acts as a middleman }\end{array}$ & Interview \\
\hline
\end{tabular}




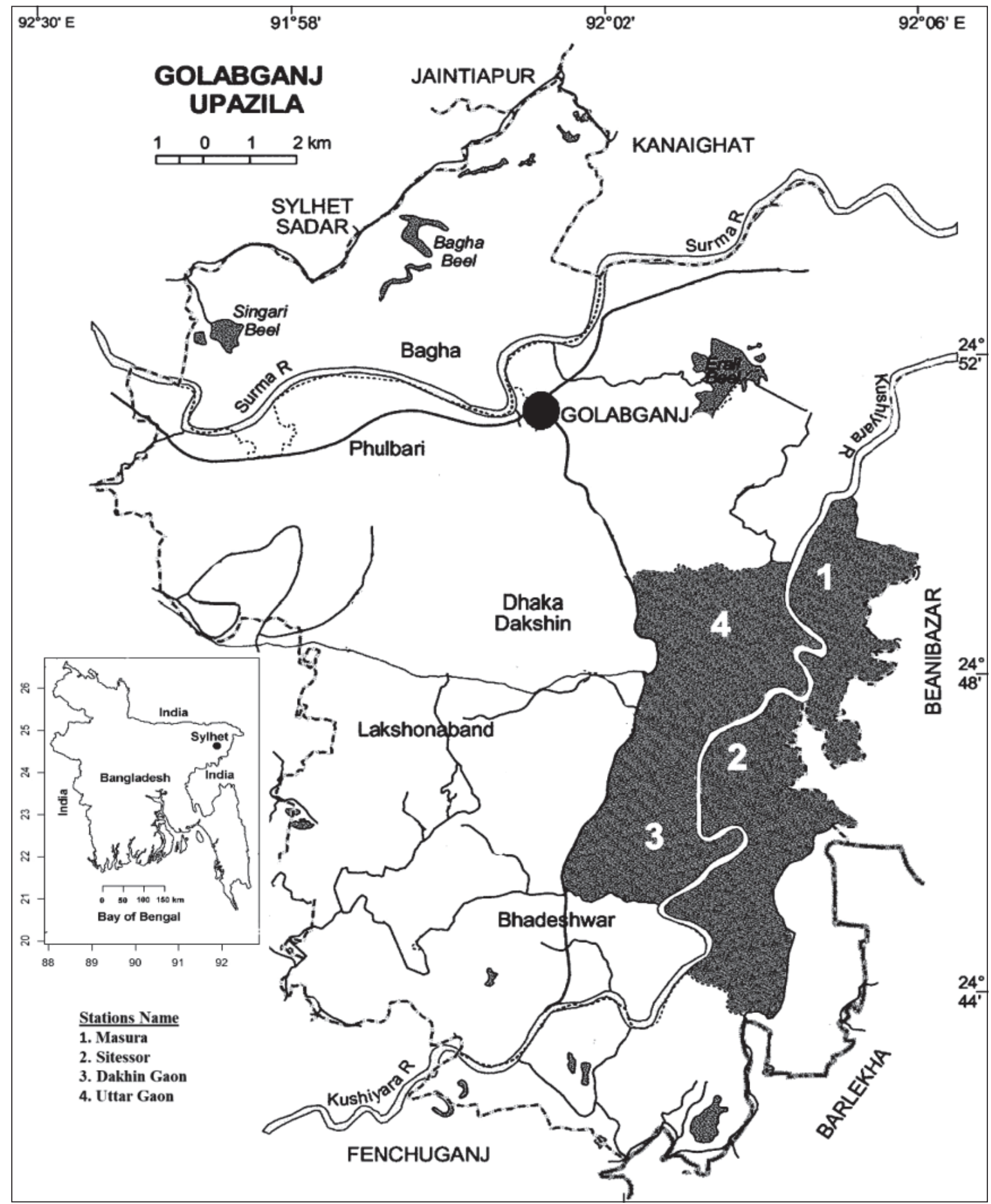

Fig. 1. Map depicting the location of the study area, Golapganj, Sylhet, Bangladesh.

\section{Catch assessment sampling}

Catch assessment surveys were performed at four main fishing grounds of the study area named Hasinar ghat, Kandir dor, Pulertol, and Barartok (Figure 1). Fish samples were directly collected from the fishing spots where sampling was performed 3 times at the same location in a week. Set bag nets (Suti jal) were deployed to capture all types and sizes of fish, with minimum selectivity, to assess species composition. When possible, fish were identified, counted, weighed in-situ, and then released onsite. Otherwise, they were preserved in $10 \%$ formalin in plastic jars for laboratory assessment. The collected fish were identified according to the description by Jhingran and Talwar (1991), Froese and Pauly (2007), and Rahman (2005). To estimate fishing gear 
efficiency, fish sampling was conducted with a set bag net, seine net, gill net, cast net, and fish traps. Each of these gears was sampled in triplicate at the same sample sites. The month-wise fish production at the four fishing grounds in the Kura River was calculated by the catch assessment method.

\section{Fish categorization and grouping}

Based on the interview and recording of the fishermen, and availability during the study period the fishes were further characterized and evaluated as commonly available (CA), moderately available (MA) and less available (LA). For the valuation of abundance and biodiversity status, the identified fishes were characterized as vulnerable (VU), endangered (EN), critically endangered (CR), and near threatened (NT) according to International Union for Conservation of Nature Red List (Mazumder et al., 2016). There were also some species evaluated but not considered as a threatened species and these were recorded as least concern (LC) fish species according to the IUCN (Table 2).

\section{Abundance and fish biodiversity}

To estimate the fish biodiversity, the ShannonWeaver diversity index (H), Margalef's richness index (D), and Pielou's evenness index (J') were calculated as $\mathrm{H}=-\Sigma \mathrm{Pi} \operatorname{lnPi}$ (Shannon \& Weaver, 1949); D = S-1 / ln N (Margalef, 1958) and J' = H / ln $\mathrm{S}$ (Pielou, 1966). Where $\mathrm{Pi}$ is the relative abundance $(\mathrm{s} / \mathrm{N}), \mathrm{s}$ is the number of individuals of one species and $\mathrm{N}$ is the total number of individuals in the sample, $\mathrm{S}$ is the total number of species, and $\ln$ is the natural logarithm.

\section{Statistical analysis}

There were no significant differences among the replicated samples means $(p>0.05)$, and the data for the different replicates were therefore averaged. Before the statistical analysis, all data were tested for normality and homogeneity of variance among the different groups using a Kolmogornov-Smirnov (K-S) test on residuals and Bartlett's test for homogeneity of variance (Sokal \& Rohlf, 1995). The month-wise fish production was compared using the one-way ANOVA technique (Zar, 1996). All results were expressed as means \pm standard error (S.E). The differences in diversity indices (diversity $\mathrm{H}$, richness $\mathrm{D}$, and evenness J') were analyzed using Past version 3.0 (Hammer et al., 2001) and all other statistical analyses were performed using Origin ${ }^{\mathrm{TM}}$ Version 9.0 and Minitab version 17 computer software (Mazumder et al., 2016), and the differences were significant at $p$-values of less than $5 \%$.
}

\section{RESULTS AND DISCUSSION}

\section{Fish biodiversity}

According to direct catch observations and information provided by the local fishermen, a total of 59 fish species under 22 families were recorded from the study area. A similar study has been reported by Rahman et al. (2015) also recorded a total of 56 species under 21 families from the Talma River of Bangladesh while only 53 fish species belonging to 28 families were recorded from the Andharmanik River of Bangladesh (Mohsin et al., 2014). These differences in fish diversity at different rivers may occur due to different geographical and physicochemical characteristics of that water body. Moreover, the health of any aquatic ecosystem depends on the abiotic characteristics of water and the biological diversity of that ecosystem, which is measured in the form of physicochemical properties. In addition, the fish diversity of any aquatic ecosystem, especially the numbers and geographical distribution depends on the physicochemical properties of that waterbody (Ingole et al., 2010; Sharma \& Shingh, 2013). However, it is exceptionally difficult to stick point one or two single factors, but several factors are interrelated for changing any aquatic biodiversity status (Raveendar et al., 2018). The present study results also exposed the Cyprinidae family as the leading fish family amongst the 22 families consisting of $29 \%$ of the total fish species composition (Figure 2). These findings are also parallel to the similar observations made by Joadder et al. (2015) in the River Padma and Galib (2015) in the River Choto Jamuna, in which the Cyprinidae family was recorded as the dominating fish family. Fishes under the Cyprinidae family were also found as the dominant fish family (consisting of $22.71 \%$ of the total fish species) in the Shari-Goyain River of Sylhet district (Talukder et al., 2021). In this regard, the recorded total number of fishes in different families, present status, and IUCN status are described in Table 2. According to respondents' survey and catch assessment period, 10 most abundant fish species were identified (Figure 3) and 21 species were recognized as commonly available throughout the year.

Taking into account all the samples collected in this study, the values of $\mathrm{H}, \mathrm{D}$, and J' were 3.599, 4.345 , and 0.921 , respectively. The value of $H$ ranged from 3.454 (April 2016) to 3.681 (October 2016), D varied from 3.404 (March 2016) to 4.889 (September 2016) and J' ranged from 0.904 (June \& September 2016) to 0.952 (March 2016). The number of fish species diversity recorded in April 2016 was 
Table 2. Fish species occurrence in the studied area with their IUCN status $(C A=$ commonly available, $M A=$ moderately available, $\mathrm{LA}=$ less available, $\mathrm{CR}=$ critically endangered, $\mathrm{EN}=$ endangered, $\mathrm{VU}=$ vulnerable, $\mathrm{NT}=$ near threatened, and $\mathrm{LC}=$ least concern)

\begin{tabular}{|c|c|c|c|c|c|}
\hline Family Name & Local Name & $\begin{array}{l}\text { Common/ } \\
\text { English Name }\end{array}$ & Scientific Name & $\begin{array}{l}\text { Present } \\
\text { Status }\end{array}$ & $\begin{array}{l}\text { IUCN } \\
\text { Status }\end{array}$ \\
\hline \multirow{17}{*}{ Cyprinidae } & Punti/Jat punti & Punti barb & Puntius sophore & $\mathrm{CA}$ & LC \\
\hline & Tit punti & Ticto barb & Puntius ticto & $\mathrm{CA}$ & LC \\
\hline & Sarputi & Olive barb & Puntius sarana & CA & LC \\
\hline & Gonia & Kuria labeo & Labeo gonius & $\mathrm{CA}$ & NT \\
\hline & Kalira/Kalibaus & Black rohu & Labeo calbasu & $\mathrm{CA}$ & LC \\
\hline & Bata/Bhangon bata & Bata labeo & Labeo bata & $\mathrm{CA}$ & LC \\
\hline & Rui & Rohu carp & Labeo rohita & MA & LC \\
\hline & Mola & Mola carplet & Amblypharyngodon mola & LA & LC \\
\hline & Boro Chela/Chelabaiya & Gora chela & Securicula gora & MA & NT \\
\hline & Silver carp & Silver carp & Hypophthalmichthys molitrix & MA & LC \\
\hline & Grass carp & Grass carp & Ctenopharyngodon idella & MA & LC \\
\hline & Mrigel/Mirka & Mrigel & Cirrhinus cirrhosus & LA & NT \\
\hline & Dhela/Gilacaki & Cotio & Osteobrama cotio & LA & NT \\
\hline & Catla & Catla & Catla catla & LA & LC \\
\hline & Carpu/Carpio & Common carp & Cyprinus carpio var. Communis & LA & LC \\
\hline & Darki/Darkina & Flying barb & Esomus danricus & LA & LC \\
\hline & Chela pata/Chela & Silver hatchet chela & Chela cachius & LA & VU \\
\hline \multirow[t]{7}{*}{ Bagridae } & Rita & Rita & Rita rita & MA & EN \\
\hline & Kalo bujuri & Tengara mystus & Mystus tengara & MA & LC \\
\hline & Ayre & Long whiskered catfish & Sperata aor & MA & VU \\
\hline & Guizza/Guizza ayer & Giant river catfish & Sperata seenghala & LA & VU \\
\hline & Tengra & Striped dwarf catfish & Mystus vittatus & CA & LC \\
\hline & Golsha & Day's mystus & Mystus bleekeri & $\mathrm{CA}$ & LC \\
\hline & Batashi & Tista batasio & Batasio batasio & LA & NT \\
\hline \multirow[t]{4}{*}{ Siluridae } & Kani pabda & Butter catfish & Ompok bimaculatus & LA & EN \\
\hline & Boal & Freshwater shark & Wallago attu & $\mathrm{CA}$ & VU \\
\hline & Pabda & Pabo catfish & Ompok pabo & CA & $\mathrm{CR}$ \\
\hline & Modhu pabda & Pabdah catfish & Ompok pabda & MA & EN \\
\hline \multirow[t]{3}{*}{ Channidae } & Shol & Banded snakehead & Channa striatus & MA & LC \\
\hline & Lata/Taki & Spotted snakehead & Channa punctatus & $\mathrm{CA}$ & LC \\
\hline & Gozar & Giant snakehead & Channa marulius & LA & EN \\
\hline \multirow[t]{3}{*}{ Mastacembelidae } & Guchi baim & Striped spiny eel & Mastacembelus pancalus & CA & LC \\
\hline & Tara baim & Spiny eel & Macrognathus aculeatus & $\mathrm{CA}$ & LC \\
\hline & Boro baim/Sal baim & Tire-track spiny eel & Mastacembelus armatus & MA & EN \\
\hline \multirow[t]{3}{*}{ Anabantidae } & Boro Khalisa & Giant gourami & Colisa fasciatus & CA & LC \\
\hline & Koi & Climbing perch & Anabas testudineus & MA & LC \\
\hline & Lal Khalisa & Dwarf gourami & Colisa Ialius & $\mathrm{CA}$ & LC \\
\hline \multirow[t]{3}{*}{ Clupeidae } & Chapila & Indian river shad & Gudusia chapra & LA & VU \\
\hline & Kachki/Guramach & Ganga river-sprat & Corica soborna & MA & LC \\
\hline & Ilish & Hilsa shad & Tenualosa ilisha & LA & LC \\
\hline \multirow[t]{2}{*}{ Cobitidae } & Bou/Rani & Necktie loach & Botia dario & MA & EN \\
\hline & Gutom/Puiya & Guntea loach & Lepidocephalus guntea & $\mathrm{CA}$ & LC \\
\hline \multirow[t]{2}{*}{ Notopteridae } & Foli & Grey featherback & Notopterus notopterus & MA & VU \\
\hline & Chital & Humped featherback & Chitala chitala & LA & EN \\
\hline \multirow[t]{2}{*}{ Schilbeidae } & Garua & Schilbid catfish & Clupisoma garua & MA & EN \\
\hline & Bacha & Batchwa vacha & Eutropiichthys vacha & LA & LC \\
\hline \multirow[t]{2}{*}{ Palaemonidae } & Sada chingri & Prawn & Macrobrachium sp. & $\mathrm{CA}$ & LC \\
\hline & Golda & Prawn & Macrobrachium rosenbergii & CA & LC \\
\hline Sisoridae & Bagair/Bagmach & Gangetic goonch & Bagarius bagarius & LA & $\mathrm{CR}$ \\
\hline Nandidae & Meni/Bheda & Mud perch & Nandus nandus & LA & NT \\
\hline Heteropneustidae & Shing & Stinging catfish & Heteropneustes fossilis & CA & LC \\
\hline Clariidae & Magur & Walking catfish & Clarias batrachus & CA & LC \\
\hline Gobiidae & Bele/Bailla & Tank goby & Glossogobius giuris & MA & LC \\
\hline Centropomidae & Lomba chanda & Elongated Glass & Chanda nama & MA & LC \\
\hline Hemiramphidae & EkThota/Ek Thuita & Congaturi halfbeak & Hyporhamphus limbatus & LA & LC \\
\hline Belonidae & Kakila/Kakla & Frashwater garfish & Xenentodon cancila & LA & LC \\
\hline Ambassidae & Gol Chanda & Indian Glass Fish & Parambassis ranga & $\mathrm{CA}$ & LC \\
\hline Ariidae & Gagla/Ghagot & Gagora catfish & Arius gagora & MA & LC \\
\hline Sciaenidae & Berkol/Koitor poa & Coitor croaker & Johnius coitor & LA & LC \\
\hline
\end{tabular}




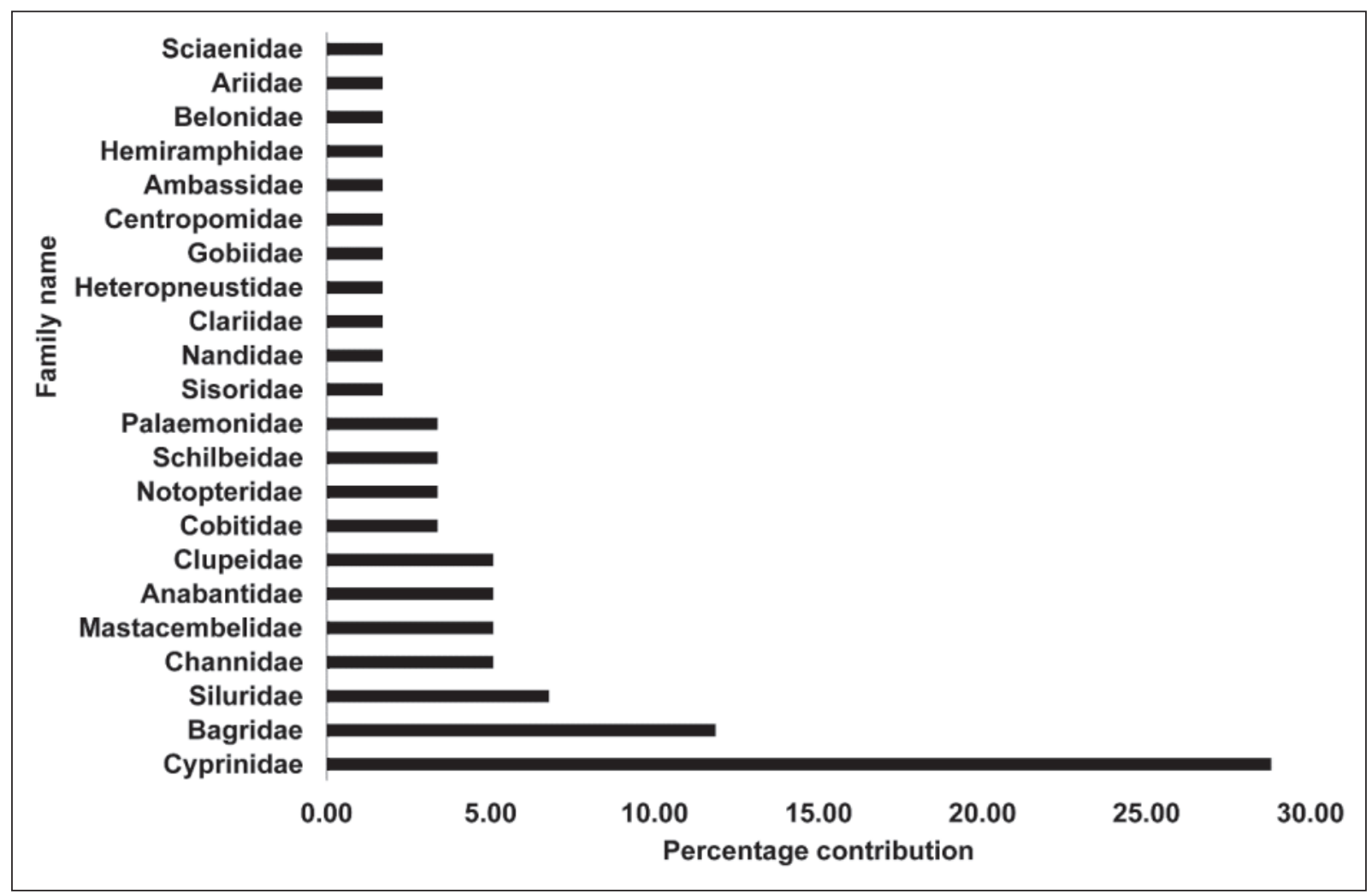

Fig. 2. Percentage of fish species diversity under different families recorded in the Kura River, Bangladesh.

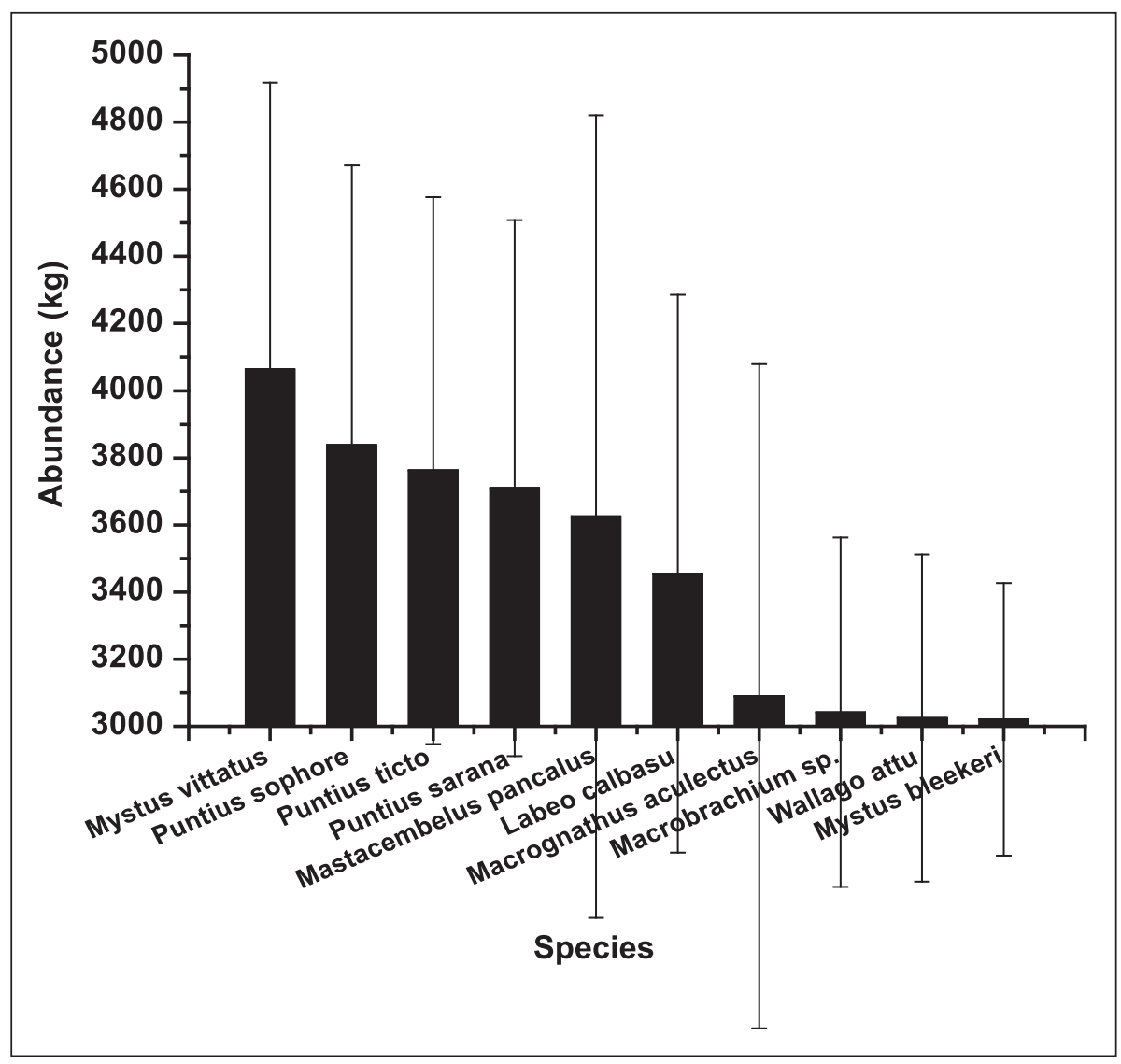

Fig. 3. Ten most abundant species were found in the study area (mean $\pm \mathrm{SE}$ ). 
significantly lowest with $\mathrm{H}$ value of 3.454 as compared to other months $(p<0.05)$. However, the $\mathrm{H}$ value was not significant between March and May $2016(p>0.05)$. The highest recorded value of $\mathrm{H}$ (October 2016) was significantly different i.e. the number of recorded fish species was comparatively high from most of the months except December 2015, January 2016, September 2016, and November 2016 $(p<0.05)$. This is because of the high availability of fishes especially during the post-monsoon period (October to November) at the Kura River ecosystem. In addition, the fishing effort (per day), as well as the increasing pressure of fishing gear during the post-monsoon period, were also responsible for the high catch value (Table 4). Moreover, the higher $\mathrm{H}$ value indicates the lowest degree of pollution with the high species diversity at any aquatic ecosystem, which also supports the present findings (Biligrami, 1988; Raveendar et al., 2018). On the other hand, the lowest value of D (March 2016) was significantly different from other months except April 2016 $(p<0.05)$. Also, the highest value of D (September 2016) was significantly different from other months except October $2016(p>0.05)$. This finding also indicates the high species richness during the late monsoon period due to the high species diversity as well as the slightly low polluted waterbody of Kura River (Biligrami, 1988; Raveendar et al., 2018). However, there was no significant difference for $\mathrm{J}$ value throughout the study period except the highest (March 2016) J value ( $p>0.05)$. This finding indicates the maximum dominance of different fish species during the month of winter (March 2016) as well as the even distribution of fish diversity (Raveendar et al., 2018). This is also because of the low water pollution of the Kura River or favorable condition for fish, which is supported by the explanation of Biligrami (1988). Biligrami (1988) has studied biodiversity index and given the degrees of pollution level of water-body based on the ranges of Shannonweaver species diversity as, slight pollution (species diversity 3.0-4.5), light pollution (species diversity 2.0-3.0), moderate pollution (species diversity 1.0-2.0) and heavy pollution (species diversity $0.0-1.0$ ), respectively. The current study results also showed values ranging from 3.454-3.681 in all the seasons, representing slight pollution based on the findings of Biligrami (1988). The results signifying the overall condition of the Kura River were found to be good with species diversity richness. However, the monthwise calculated values of Shannon-Weaver diversity (H), Margalef's richness (D), and Pielou's evenness (J') were presented in Table 3.

\section{Threatened fish species}

Out of the recorded 59 fish species, 37 species were the least concern, and 6 species were near threatened (NT). Among the remaining 16 fish species $(27 \%), 6$ species were ranked as vulnerable (10\%), 8 as endangered (14\%), and 2 as critically endangered $(3 \%)$ recorded in the study area (Figure 4 \& 5) (International Union for Conservation of Nature, 2015). However, according to the respondents' feedback, these species were abundant in previous decades but now recorded as threatened because of increasing fishing pressure, gradually

Table 3. Diversity index of fish assemblages from all the sampling points of the Kura River

\begin{tabular}{|c|c|c|c|c|c|}
\hline Month & $\begin{array}{l}\text { Number of } \\
\text { species (S) }\end{array}$ & $\begin{array}{l}\text { Total Number of } \\
\text { individuals }(\mathrm{N})\end{array}$ & Diversity, H & Richness, D & Evenness, J' \\
\hline July, 16 & 55 & 87102 & 3.630 & 4.747 & 0.906 \\
\hline August,16 & 55 & 87084 & 3.631 & 4.747 & 0.906 \\
\hline September,16 & 57 & 94210 & 3.656 & 4.889 & 0.904 \\
\hline \multicolumn{6}{|l|}{ Monsoon } \\
\hline October,16 & 57 & 99966 & 3.681 & 4.864 & 0.910 \\
\hline November,16 & 56 & 100652 & 3.673 & 4.775 & 0.912 \\
\hline \multicolumn{6}{|l|}{ Post-monsoon } \\
\hline December,15 & 55 & 93911 & 3.680 & 4.716 & 0.918 \\
\hline January, 16 & 50 & 77467 & 3.662 & 4.353 & 0.936 \\
\hline February,16 & 46 & 73472 & 3.619 & 4.016 & 0.945 \\
\hline March,16 & 39 & 70580 & 3.489 & 3.404 & 0.952 \\
\hline \multicolumn{6}{|l|}{ Winter } \\
\hline April,16 & 40 & 75313 & 3.454 & 3.473 & 0.936 \\
\hline May,16 & 44 & 78476 & 3.478 & 3.815 & 0.919 \\
\hline June,16 & 50 & 80042 & 3.536 & 4.340 & 0.904 \\
\hline \multicolumn{6}{|l|}{ Summer } \\
\hline Average & 59 & 1018275 & 3.599 & 4.345 & 0.921 \\
\hline
\end{tabular}




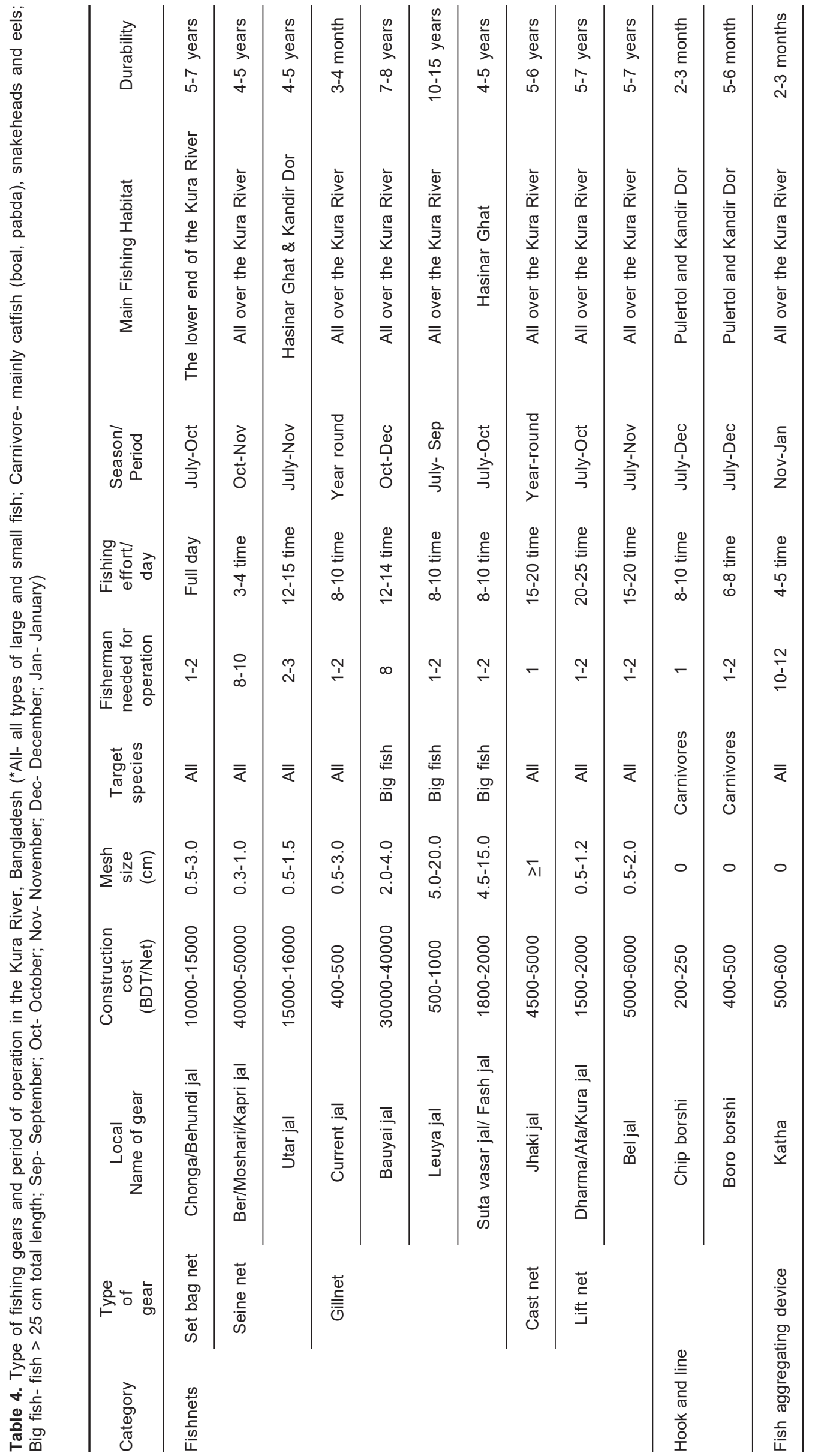




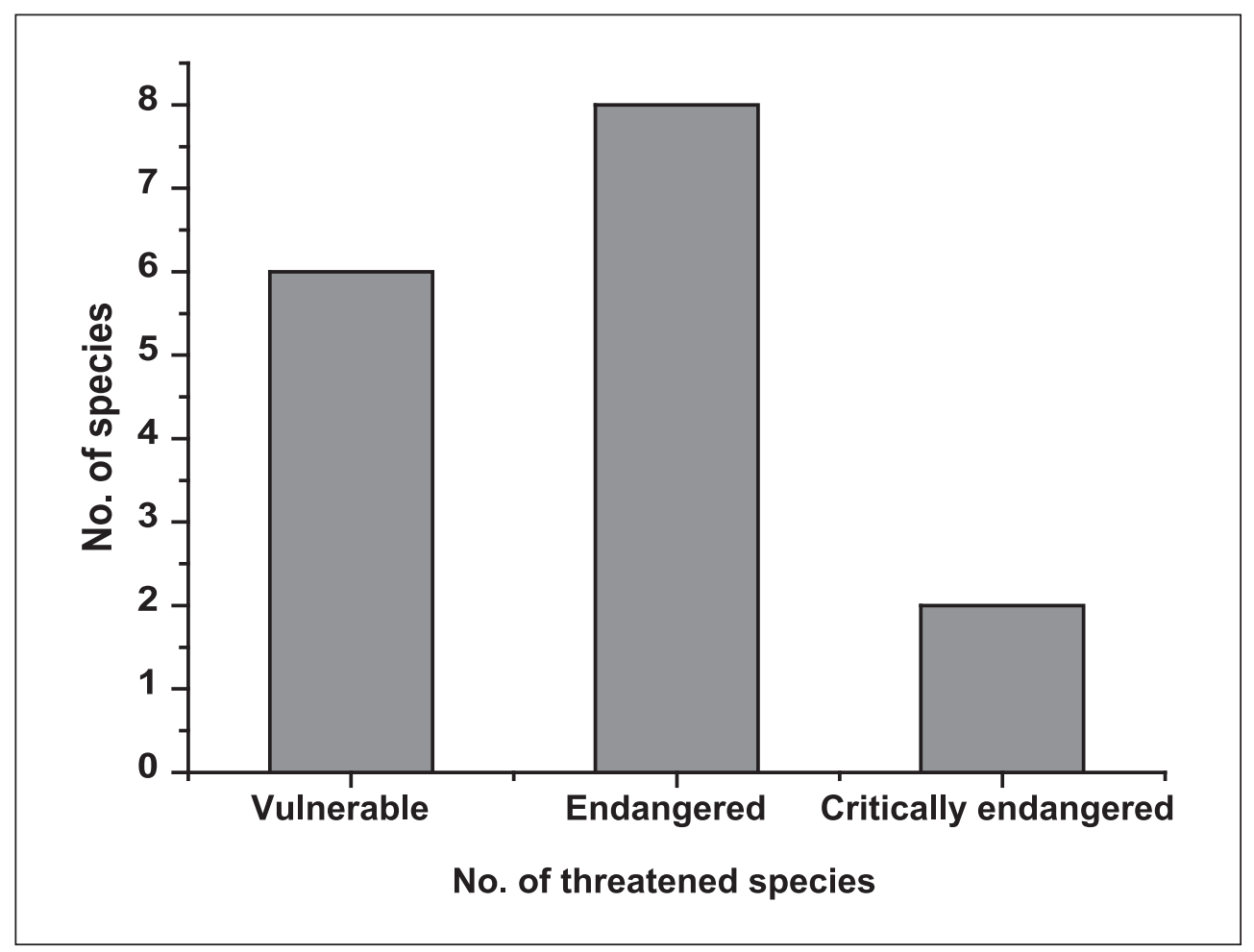

Fig. 4. Threatened fish species found in the study area according to the International Union for Conservation of Nature (IUCN 2015).

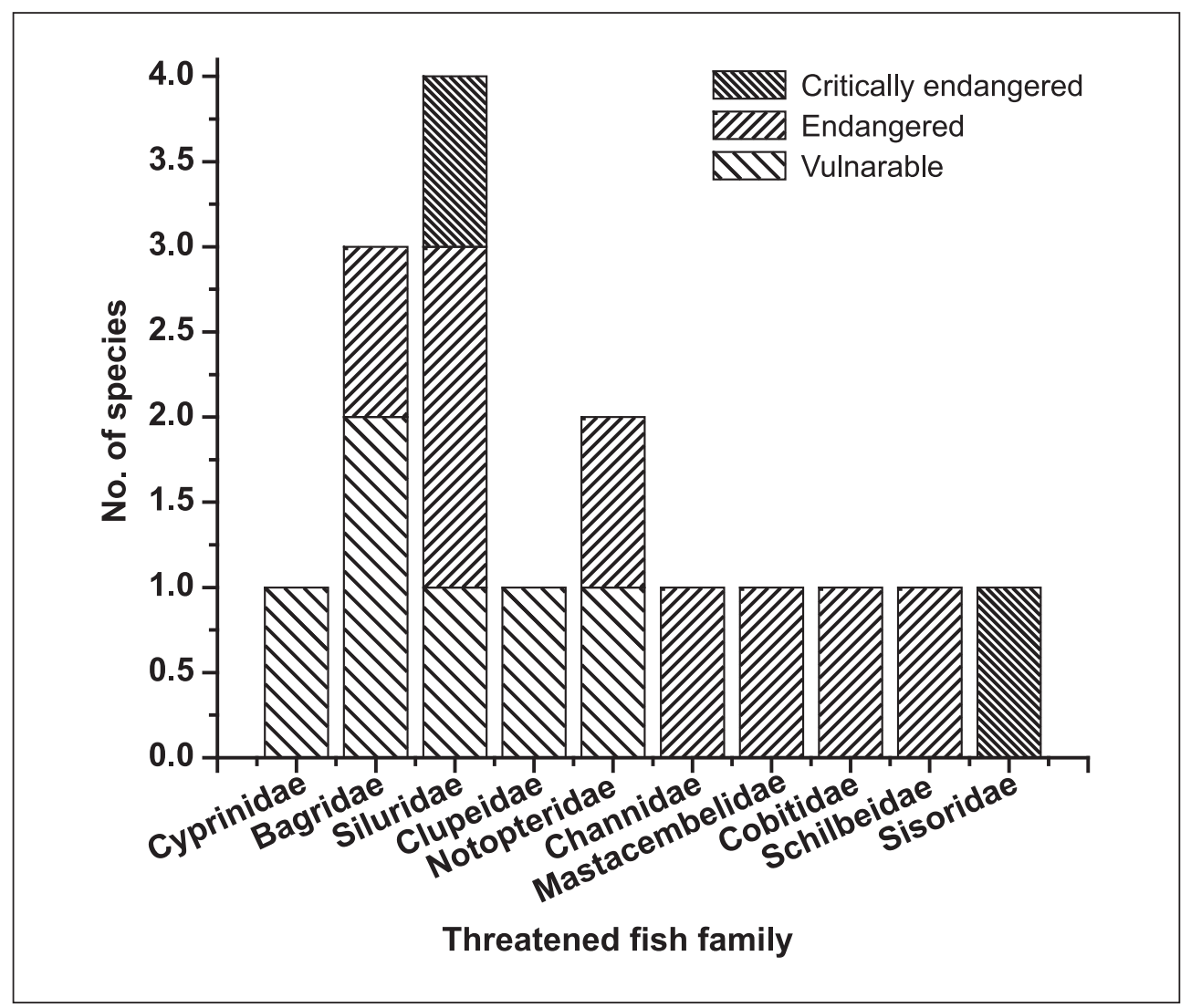

Fig. 5. Several threatened fishes under different families were recorded from the study area (Kura River), Golapganj, Bangladesh. 
reducing water flow due to upstream barrier, increased pressure of destructive fishing gears, etc. However, several parallel studies by Joadder et al. (2015) at the River Padma and Talukder et al. (2021) at the Srari-Goyain River of Sylhet district of Bangladesh have found 28 and 19 fish species as threatened, respectively. Therefore, the suitability of feeding, breeding, and nursing ground of different water bodies may cause different calculations and identification of threatened fish species at different Rivers and underline the necessity of fast improved conservation management (Talukder et al., 2021).

\section{Fishing gears}

Kura River is considered rich in fish diversity and so as fishing gear. A total of thirteen (13) diversified fishing gears under three main categories- fishnets, hook and lines, and fish aggregating devices were identified and documented from the study area (Table 4). Set bag net, seine nets, gill nets, cast nets and different types of hooks and lines were used as the major fishing gears by the fishers in the study area. Several parallel studies with similar findings have also been reported by Siddiq et al. (2013) at Dogger Beel and Islam et al. (2016) at Jamuna River, who identified also thirteen (13) fishing gears but mostly under 5 major groups (due to locally made different fishing gear type), namely, fish nets, fish traps, hooks and lines, spears/wounding gears and khata/zag. Most of the recorded fishing gears were used during the monsoon to the post-monsoon period (July to January), except the gill net (current jal) and cast net (jhaki jal) which were identified as year-round using gear in the study area, respectively. A similar observation was reported by Siddiq et al. (2013) in which the current jal was used around the year to catch most of the species at Dogger Beel. In contrast, the present findings identified another two types of gear-gill net (leuya jal) and lift net (dharma jal) were recorded only been used during the monsoon period, but the fish aggregating device (Katha fishing) were especially used and recorded during the post-monsoon period (November to January), respectively. The present study also identified many special types of fishing gears from different fishing grounds, such as- seine net (uttar jal) from Hasinar ghat and Kandir dor, gill net (suta vasar jal) in Hasinar ghat, chip borshi, and boro borshi used especially in Pulertol and Kandir dor fishing ground. The present study identified the seasonal variability for using different fishing gears at Kura River. The use of different fishing gears and the operational time mostly depends on the habitat or fishing grounds type, water level, an abundance of species, etc. (Siddiq et al., 2013). Additionally, the catch composition of different fish species varies with season and so varies with fishing gears. The significant differences in species composition and richness between different sampling gears depend on habitat or fishing ground type, which supports the present study findings (Siddiq et al., 2013; Paiva de Affonso et al., 2016). The high abundance with increased catch value of fishes is highly responsible for increasing fishing activities during the monsoon and post-monsoon periods were observed in the present study. Higher fishing activities were reported by Dewan and Mazid (1994) using different fishing techniques in Bangladesh during the monsoon and post-monsoon period.

\section{Fish production}

The catch assessment method was applied to calculate the fish production from four fishing grounds in the Kura River. The highest fish production $(19800 \pm 7722.71 \mathrm{~kg})$ was recorded in November 2016 at the Kandir Dor fishing ground, which was significantly higher than all other months $(p<0.05)$. The Kandir Dor is comparatively deeper than all other fishing ground, may cause of the high species abundance. During the post-monsoon period (October-November), high fishing activities were performed in the Kura river and Kandir Dor as well supposed to high catch composition and highest fish production.

In contrast, the fish production $(225 \pm 110.65 \mathrm{~kg})$ at Barartok fishing ground in March 2016 was significantly lower than in all other study months $(p<0.05$; Figure 6$)$. Hence, the Barartok fishing ground is reported as the lowest depth of all other fishing grounds of the Kura River. Also, the lowest species abundance, richness, and catch composition were estimated in March during the winter season (December-March). However, the total fish production $(\mathrm{kg} / \mathrm{ha})$ from January to December, has been recorded at $41153.85 \mathrm{~kg} / \mathrm{ha}, 32548.57 \mathrm{~kg} / \mathrm{ha}$, $29374.76 \mathrm{~kg} / \mathrm{ha}$, and $21814.83 \mathrm{~kg} / \mathrm{ha}$, respectively, from Kandir Dor, Hasinar Ghat, Pulertol and Barartok fishing grounds. The depth, water quality, and catch composition of the four fishing grounds of Kura River made different from each other. Moreover, the geo-morphological parameter such as depth/altitudes is considered as the most significant character than physicochemical parameters of any water body, which may affect different fish production at four fishing grounds of Kura River (Welcomme et al., 2006; Suvarnaraksha et al., 2012). Therefore, the richness and production of fish species are firmly bound to the inundating pattern during the monsoon period (Ahmed 1991), in which the fish production of the Kura River has been recognized higher at monsoon (July to September) and post-monsoon (October to December) period as well. 


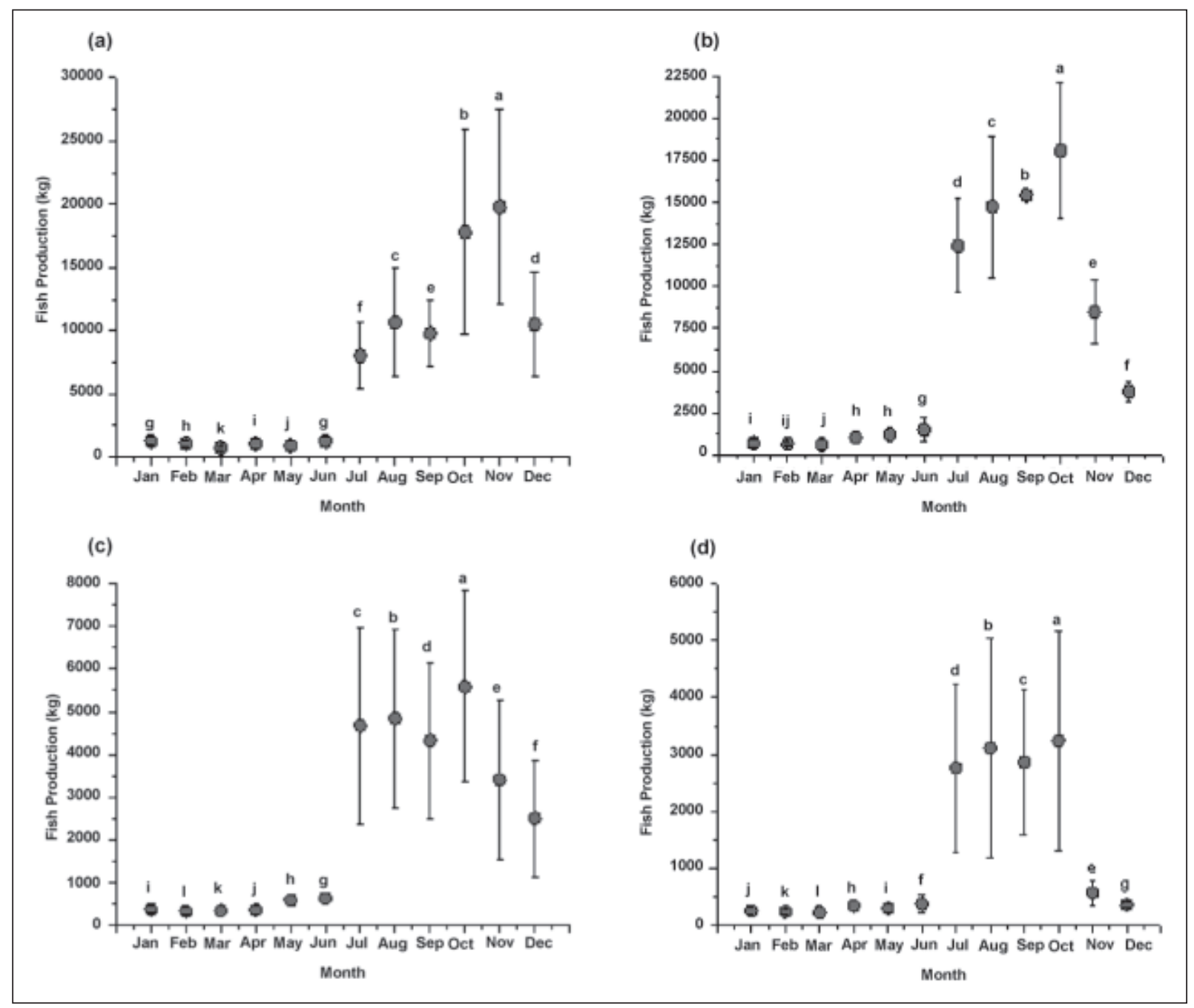

Fig. 6. Month-wise total fish production (kg) at four fishing grounds in the Kura River, (a) Kandir Dor; (b) Hasinar Ghat; (c) Pulertol; and (d) Barartok. Values are presented as mean \pm standard error (S.E). Different letters indicate significant differences by month $(p<0.05)$.

Table 5. Factors/reasons for fish habitat change in the Kura River, Bangladesh

\begin{tabular}{llcc}
\hline SL. & \multicolumn{1}{c}{ Reasons } & $\begin{array}{c}\text { No. of } \\
\text { No. }\end{array}$ & $\begin{array}{c}\text { Percentage of } \\
\text { respondents }\end{array}$ \\
\hline 1. & $\begin{array}{l}\text { Blockage of the upstream connecting channel (khal) of the river that } \\
\text { might be disturbed in fish migration }\end{array}$ & 70 & $87.5 \%$ \\
2. & Use of illegal/destructive fishing gears (Chonga/Behundi jal and current jal) & 65 & $81.25 \%$ \\
3. & Decreasing water depth and current, increasing siltation & 62 & $77.5 \%$ \\
4. $\quad$ Increasing fisherman and fishing pressure & 60 & $75.0 \%$ \\
5. & Catching of juvenile and brood fishes & 38 & $47.5 \%$ \\
6. $\quad$ Use as navigational route resulting fishes were disturbed their breeding & 28 & $35.0 \%$ \\
& and migration purposes & 16 & $20.0 \%$ \\
7. $\quad$ Bottom fishing by illegal gears (Ber jal) that damage bottom and surrounding habitat & 10 & $12.5 \%$ \\
8. & High rate of katha fishing & & \\
\hline
\end{tabular}




\section{Reasons for fish habitat change}

Loss of fish habitat degradation is an alarming issue for decreasing fish diversity in any aquatic ecosystem. Due to the high level of anthropogenic pressure (dam construction, pollution, land erosion, overexploitation, etc.), the freshwater fish population facing serious threats around the world (Magurran, 2009; Arthington et al., 2016; Guo et al., 2018). Thus, the present study results were identified several threats for reducing fish biodiversity and habitat degradation of the Kura River fishery, presented in Table 5. Undisturbed fish habitat is an essential part of maintaining healthy fish populations, although the upstream blockage was declared as the prime cause of habitat change in the Kura River followed by the use of illegal fishing gears, siltation, an increase of fishing pressure, catching of juvenile and brood fishes, local navigational route, high rate of katha fishing (aggregation of fishes by using aggregating devices such as- making bush of tree branches, aquatic weeds, etc. for attracting fish and then catching all the fishes by using seine net). Alteration of river flow due to dam construction is considered as one of the strongest threats for directly damaging and reducing river habitat (Vörösmarty et al., 2010). Furthermore, overexploitation and year-round use of destructive fishing gears (illegal fishing gears) are also considered as the principal cause of fish habitat destruction as well as declining fish diversity (Guo et al., 2018; Jahan et al., 2020). Similar results were also observed by Pandit et al. (2015b) at Soma Nadi Jalmohal and Rahman et al. (2015) at Talma River of Bangladesh, who stated that the exploitation, siltation, flooding, drought, construction of obstacles for fish migration as the key causes of decline fish habitat and biodiversity in Bangladesh, respectively. Thus, all the clear destructive factors respond with the sustainability of fish diversity habitat loss at any river ecosystem (Guo et al., 2018; Jahan et al., 2020). Therefore, the management strategy and the conservation process of fish diversity at Kura River have become more important.

\section{CONCLUSION}

The present study has documented the baseline scenario of the Kura River wherein the current fish biodiversity status, as well as the main threats to fish biodiversity, have been figure out. Cyprinidae family was recorded as the dominating fish family. During the post-monsoon season (October-November), the Kura River provided the highest fish biodiversity and catch. The present study identified 6 vulnerable, 8 endangered and 2 critically endangered species while the respondents' evaluation reported the number of threatened species is increasing. Blockage of the upstream connecting channel (khal), use of illegal/ destructive fishing gears (e.g. Chonga/Behundi jal \& current jal), decreasing water depth, and increasing fishing pressure was identified as serious threats to the Kura River, which affects the overall fish production of this resourceful ecosystem. Therefore, the findings of this study exposed that the conservation of fishes has become urgent, more hotspots should be identified as nature reserves, and an integrated management plan should, therefore, be developed and implemented effectively.

\section{ACKNOWLEDGEMENTS}

This study was supported by the project of the University Grants Commission (UGC) of Bangladesh. We thank Swapan Shingh, Bhupal Roni, Monju, and all the members of the Aquatic Resource Management laboratory for their participation and assistance during the field trips.

\section{REFERENCES}

Ahmed, M. 1991. A model to determine benefits obtainable from the management of riverine fisheries of Bangladesh. WorldFish. p. 728.

Arthington, A.H., Dulvy, N.K., Gladstone, W. \& Winfield, I.J. 2016. Fish conservation in freshwater and marine realms: status, threats and management. Aquatic Conservation: Marine and Freshwater Ecosystems, 26(5): 838-857.

Banglapedia, 2015. National Encyclopedia of Bangladesh. Asiatic society of Bangladesh, Dhaka.

Biligrami, K.S. 1988. Biological monitoring of rivers, problems and prospects in India. Aquatic Ecotoxicology, 37: 245-250.

Chaki, N., Jahan, S., Fahad, M.F.H., Galib, S.M. \& Mohsin, A.B.M. 2014. Environment and fish fauna of the Atrai River: global and local conservation perspective. Journal of Fisheries, 2(3): 163-172.

Dewan, S. \& Mazid, M.A. 1994. Productivity, exploitation and fishing technology of Inland open water fisheries, Bangladesh. Assistance of Fisheries Research Institute"(BGD/89/OV) FRI/ FAO/UNDP.

Froese, R. \& Pauly, D. 2007. Fishbase, Concept, Design and Data Sources. International Center of Living Aquatic Resources Management (ICLARM), Manila.

Galib, S.M. 2015. Fish fauna of the Brahmaputra River, Bangladesh: richness, threats and conservation needs. Journal of Fisheries, 3(3): 285-292. 
Galib, S.M., Naser, S.M.A., Mohsin, A.B.M., Chaki, N. \& Fahad, F.H. 2013. Fish diversity of the River Choto Jamuna, Bangladesh: Present status and conservation needs. International Journal of Biodiversity and Conservation, 5(6): 389-395.

Guo, Q., Liu, X., Ao, X., Qin, J., Wu, X. \& Ouyang, S. 2018. Fish diversity in the middle and lower reaches of the Ganjiang River of China: Threats and conservation. PLOS ONE, 13(11): e0205116.

Hammer, Ø., Harper, D.A.T. \& Ryan, P.D. 2001. PAST: Paleontological statistics software package for education and data analysis. Palaeontologia Electronica, 4(1): 1-9.

Imteazzaman, A.M. \& Galib, S.M. 2013. Fish fauna of Halti Beel, Bangladesh. International Journal of Current Research, 5(1): 187-190.

Ingole, S.B., Naik, S.R. \& Kadam, G. 2010. Study of phytoplankton of freshwater reservoir at majalgaon on sindphana river district beed (MS). International Research Journal, 1(13): 87 88.

International Union for Conservation of Nature (IUCN), Bangladesh. 2015. Red book of threatened fishes of Bangladesh, IUCN. The World Conservation Union, Dhaka.

Islam, M.A., Islam, M.J., Barman, S.K., Morshed, F. \& Marine, S.S. 2015. Study on present status of fish biodiversity in wetlands of Sylhet District, Bangladesh. Agriculture, Forestry and Fisheries, 4(6): 296-299.

Islam, S.M., Rahman, M.B., Alam, M.R., Mithun, B.D., Bal, A., Azam, M. \& Ruma, M. 2016. A case study on fishing gears, fish species composition and fisher folk community at Jamuna River of Sirajganj Sadar Fish Landing Site, Bangladesh. Journal of Aquatic Science, 4(1): 11-19.

Jahan, M.T., Hossen, S., Sharker, M.R., Sukhan, Z.P., Hossain, M.B., Ali, M.M. \& Shadin, M.K.S. 2020. Assessment of fish diversity in the Baleshwari River: Present status, threats and conservation perspectives. World Journal of Fish and Marine Sciences, 12(1): 6-15.

Jhingran, A.G. \& Talwar, P.K. 1991. Inland Fishes of India and Adjacent Countries. Oxford and IBH Publishing Co., Pvt. Ltd., New Delhi.

Joadder, M.A.R., Galib, S.M., Haque, S.M.M. \& Chaki, N. 2015. Fishes of the river Padma, Bangladesh: Current trend and conservation status. Journal of Fisheries, 3(2): 259-266.

Magurran, A.E. 2009. Threats to freshwater fish. Science, 325: 1215-1216.

Margalef, R. 1958. Perspectives in Ecological Theory. University of Chicago Press, Chicago.
Mazumder, S.K., Das, S.K., Bakar, Y. \& Ghaffar, M.A. 2016. Effects of temperature and diet on lengthweight relationship and condition factor of the juvenile Malabar blood snapper (Lutjanus malabaricus Bloch \& Schneider, 1801). Journal of Zhejiang University, 17(8): 580-90.

Mazumder, S.K., Simon, K.D., Saleh, M.R. \& Mazlan, A.G. 2018. Temperature and diet effect on the pepsin enzyme activities, digestive somatic index and relative gut length of Malabar blood snapper (Lutjanus malabaricus Bloch \& Schneider, 1801). Aquaculture Reports, 9: 1-9.

Mohsin, A.B.M., Yeasmin, F., Galib, S.M., Alam, B. \& Haque, S.M.M. 2014. Fish fauna of the Andharmanik River in Patuakhali, Bangladesh. Middle-East Journal of Scientific Research, 21(5): 802-807.

Paiva de Affonso, I., Gomes, L.C., Agostinho, A.A., Latini, J.D. \& García-Berthou, E. 2016. Interacting effects of spatial gradients and fishing gears on characterization of fish assemblages in large reservoirs. Reviews in Fish Biology and Fisheries, 26(1): 71-81.

Pandit, D., Kunda, M., Harun-Al-Rashid, A., Sufian, M.A. \& Mazumder, S.K. 2015a. Present status of fish biodiversity in Dekhar Haor, Bangladesh: A case study. World Journal of Fish and Marine Sciences, 7(4): 278-87.

Pandit, D., Kunda, M., Islam, M.J., Islam, M.A. \& Barman, P.P. 2015b. Assessment of present status of fish diversity in Soma Nadi Jalmohal of Sunamganj in Bangladesh. Journal of Sylhet Agricultural University, 2(1): 127-135.

Pielou, E.C. 1966. Species-diversity and patterndiversity in the study of ecological succession. Journal of Theoretical Biology, 10(2): 370-383.

Rahman, A.K.A. 2005. Freshwater fishes of Bangladesh. In: Zoological Society of Bangladesh. M.A. Howlader (Ed.). University of Dhaka, Dhaka, Bangladesh. pp. 394+XVIII.

Rahman, M.A., Mondal, M.N., Hannan, M.A. \& Habib, K.A. 2015. Present status of fish biodiversity in Talma River at Northern part of Bangladesh. International Journal of Fisheries and Aquatic Studies, 3(1): 341-348.

Raveendar, B., Sharma, A.P., Gurjar, U.R., Gugulothu, R. \& Mishra, A. 2018. Assessment the present status of fish diversity in relation to physicochemical characteristics of Nanaksagar reservoir of Uttrakhand. Journal of Entomology and Zoology Studies, 6(2): 477-484. 
Shannon, C.E. \& Weaver, W. 1949. The Mathematical Theory of Communication. University of Illinois Press, Illinois.

Sharma, D.K. \& Singh, R.P. 2013. Correlation between physico-chemical parameters and phytoplanktons of Tighra reservoir, Gwalior, Madhya Pradesh. International Journal of Security and Networks, 4(1): 90-95.

Siddiq, M.A., Miah, M.I., Ahmed, Z.F. \& Asaduzzaman, M. 2013. Present status of fish, fishers and fisheries of Dogger Beel in Hajigonj Upazila, Chandpur, Bangladesh. Journal of Aquatic Science, 1(2): 39-45.

Sokal, R.R. \& Rohlf, F.J. 1995. Biometry: The Principles and Practice of Statistics in Biological Research. W.H. Freeman and Company, New York.

Suvarnaraksha, A., Lek, S., Lek-Ann, S. \& Jutagate, T. 2012. Fish diversity and assemblage patterns along the longitudinal gradient of a tropical river in the IndoBurma hotspot region (Ping-Wang River Basin). Hydrobiologia, 694(5): 153-169.
Talukder, M.R., Hussain, M.A., Kunda, M., Rashid, A.H.A., Pandit, D. \& Sumon, T.A. 2021. Checklist of fish species in the Shari-Goyain river, Bangladesh: Threats and conservation measures. Indian Journal of Geo Marine Sciences, 50(02): 148-155.

Vörösmarty, C.J., McIntyre, P.B., Gessner, M.O., Dudgeon, D., Prusevich, A., Green, P., Glidden, P.S., Bunn, S.E., Sullivan, C.A., Reidy Liermann, C. \& Davies, P.M. 2010. Global threats to human water security and river biodiversity. Nature, 467(7315): 555-561.

Welcomme, R.L., Winemiller, O.K. \& Cowx, I.G. 2006. Fish environmental guilds as a tool for assessment of ecological condition of rivers. River Research \& Applications, 22: 377-396.

Zar, J.H. 1996. Biostatistical Analysis. 3rd Ed. Prentice Hall, Upper Saddle River, New Jersey. 